\title{
Assessing the influence of groundwater and land surface scheme in the modelling of land surface-atmosphere feedbacks over the FIFE area in Kansas, USA
}

Larsen, Morten Andreas Dahl; Højmark Rasmussen, Søren; Drews, Martin; Butts, M.B.; Christensen, J.H.; Refsgaard, J.C.

\section{Published in:}

Environmental Earth Sciences

Link to article, DOI:

$10.1007 / \mathrm{s} 12665-015-4919-0$

Publication date:

2016

Document Version

Peer reviewed version

Link back to DTU Orbit

Citation (APA):

Larsen, M. A. D., Højmark Rasmussen, S., Drews, M., Butts, M. B., Christensen, J. H., \& Refsgaard, J. C. (2016). Assessing the influence of groundwater and land surface scheme in the modelling of land surfaceatmosphere feedbacks over the FIFE area in Kansas, USA. Environmental Earth Sciences, 75, [130]. https://doi.org/10.1007/s12665-015-4919-0

\section{General rights}

Copyright and moral rights for the publications made accessible in the public portal are retained by the authors and/or other copyright owners and it is a condition of accessing publications that users recognise and abide by the legal requirements associated with these rights.

- Users may download and print one copy of any publication from the public portal for the purpose of private study or research.

- You may not further distribute the material or use it for any profit-making activity or commercial gain

- You may freely distribute the URL identifying the publication in the public portal 


\section{Environmental Earth Sciences}

\section{Assessing the influence of groundwater and land surface scheme in the modelling of land surface-atmosphere feedbacks over the FIFE area in Kansas, USA

\author{
--Manuscript Draft--
}

\begin{tabular}{|c|c|}
\hline \multicolumn{2}{|l|}{ Manuscript Number: } \\
\hline Full Title: & $\begin{array}{l}\text { Assessing the influence of groundwater and land surface scheme in the modelling of } \\
\text { land surface-atmosphere feedbacks over the FIFE area in Kansas, USA }\end{array}$ \\
\hline Article Type: & Original Manuscript \\
\hline Corresponding Author: & $\begin{array}{l}\text { Morten Andreas Dahl Larsen, Ph.D. } \\
\text { Technical University of Denmark } \\
\text { Roskilde, DENMARK }\end{array}$ \\
\hline \multicolumn{2}{|l|}{$\begin{array}{l}\text { Corresponding Author Secondary } \\
\text { Information: }\end{array}$} \\
\hline Corresponding Author's Institution: & Technical University of Denmark \\
\hline \multicolumn{2}{|l|}{$\begin{array}{l}\text { Corresponding Author's Secondary } \\
\text { Institution: }\end{array}$} \\
\hline First Author: & Morten Andreas Dahl Larsen, Ph.D. \\
\hline \multicolumn{2}{|l|}{ First Author Secondary Information: } \\
\hline \multirow[t]{6}{*}{ Order of Authors: } & Morten Andreas Dahl Larsen, Ph.D. \\
\hline & Søren Højmark Rasmussen, Ph.d. \\
\hline & Martin Drews, Ph.D. \\
\hline & Michael Brian Butts, Ph.D. \\
\hline & Jens Hesselbjerg Christensen, Ph.D. \\
\hline & Jens Christian Refsgaard, Dr. Scient \\
\hline \multicolumn{2}{|c|}{ Order of Authors Secondary Information: } \\
\hline Abstract: & $\begin{array}{l}\text { The land surface-atmosphere interaction is described differently in large scale surface } \\
\text { schemes of regional climate models and small scale spatially distributed hydrological } \\
\text { models. In particular, the hydrological models include the influence of shallow } \\
\text { groundwater on evapotranspiration during dry periods where soils are depleted and } \\
\text { groundwater is the only water supply. These mechanisms are analysed by combining a } \\
\text { distributed hydrological model (MIKE SHE) and a regional climate model (HIRHAM) } \\
\text { and comparing simulation results to the FIFE area observation data in Kansas, USA. } \\
\text { The numerical experiments include five simulations. First MIKE SHE is forced by } \\
\text { observed climate data in two versions i) with groundwater at a fixed uniform depth, and } \\
\text { ii) with a dynamical groundwater component simulating shallow groundwater conditions } \\
\text { in river valleys. iii) In a third simulation MIKE SHE is forced by HIRHAM simulated } \\
\text { precipitation. The last two simulations include iv) a standard HIRHAM simulation, and } \\
\text { v) a fully coupled HIRHAM-MIKE SHE simulation locally replacing the land surface } \\
\text { scheme by MIKE SHE for the FIFE area, while HIRHAM in standard configuration is } \\
\text { used for the remaining model area. } \\
\text { The results show a clear correlation between depth to the groundwater and } \\
\text { evapotranspiration with a distinct groundwater depth threshold at } 0.5-3 \text { m. During the } \\
\text { dry summer period the two MIKE SHE simulations using distributed groundwater } \\
\text { reproduced evapotranspiration better than MIKE SHE with unsaturated flow alone and } \\
\text { the HIRHAM simulations. This indicates that including dynamic groundwater in a fully } \\
\text { coupled climate-hydrological model may improve evapotranspiration fluxes from areas } \\
\text { with shallow groundwater tables. }\end{array}$ \\
\hline Suggested Reviewers: & $\begin{array}{l}\text { Jehan Rihani, Ph.D. } \\
\text { Scientist, University of Bonn } \\
\text { jrihani@uni-bonn.de } \\
\text { Knowledge on land surface/atmosphere interaction also in North American settings }\end{array}$ \\
\hline
\end{tabular}


Reed Maxwell, Ph.D.

Professor, Colorado School of Mines

maxwell@mines.edu

High degree of expertise in land surface/groundwater/atmosphere interaction.

Opposed Reviewers: 


\title{
Assessing the influence of groundwater and land surface scheme in the modelling of land surface-atmosphere feedbacks over the FIFE area in Kansas, USA
}

\author{
M.A.D. Larsen ${ }^{1 *}$, S. H. Rasmussen ${ }^{2}$, M. Drews ${ }^{1}$, M. B. Butts ${ }^{3}$, J. H. Christensen ${ }^{4}$ and J. C. \\ Refsgaard $^{5}$
}

1) Technical University of Denmark (DTU), Frederiksborgvej 399, DK-4000 Roskilde, Denmark

2) EnviDan A/S, Fuglebækvej 1A, DK-2770 Kastrup, Denmark

3) DHI, Agern Allé 5, DK-2970 Hørsholm, Denmark

4) Danish Meteorological Institute (DMI), Lyngbyvej 100, DK-2100 Copenhagen, Denmark

5) Geological Survey of Greenland and Denmark (GEUS), Øster Voldgade 10, DK-1350 Copenhagen K, Denmark

*) Corresponding author, madla@dtu.dk, 0045-25119895

\begin{abstract}
The land surface-atmosphere interaction is described differently in large scale surface schemes of regional climate models and small scale spatially distributed hydrological models. In particular, the hydrological models include the influence of shallow groundwater on evapotranspiration during dry periods where soils are depleted and groundwater is the only water supply. These mechanisms are analysed by combining a distributed hydrological model (MIKE SHE) and a regional climate model (HIRHAM) and comparing simulation results to the FIFE area observation data in Kansas, USA. The numerical experiments include five simulations. First MIKE SHE is forced by observed climate data in two versions i) with groundwater at a fixed uniform depth, and ii) with a dynamical groundwater component simulating shallow groundwater conditions in river valleys. iii) In a third simulation MIKE SHE is forced by HIRHAM simulated precipitation. The last two simulations include iv) a standard HIRHAM simulation, and v) a fully coupled HIRHAM-MIKE SHE simulation locally replacing the land surface scheme by MIKE SHE for the FIFE area, while HIRHAM in standard configuration is used for the remaining model area.

The results show a clear correlation between depth to the groundwater and evapotranspiration with a distinct groundwater depth threshold at 0.5-3 m. During the dry summer period the two MIKE SHE simulations using distributed groundwater reproduced evapotranspiration better than MIKE SHE with unsaturated flow alone and the HIRHAM simulations. This indicates that including dynamic groundwater in a fully coupled climate-hydrological model may improve evapotranspiration fluxes from areas with shallow groundwater tables.
\end{abstract}

Keywords: Land surface - atmosphere interactions, land surface processes, regional climate modelling, evapotranspiration, groundwater 


\section{Introduction}

The hydrological cycle has traditionally been studied in two separate parts. The climate and meteorological communities have developed models describing the atmospheric part with redistribution of energy and moisture, while hydrologists have developed models for the terrestrial part including processes for river, soil moisture and groundwater (Shelton 2009). As a result hydrological impact studies of climate change have generally been carried out by simply forcing hydrological models with output from climate models (e.g. Graham et al. 2007; van Roosmalen et al. 2007). In this type of approach, feedback from the terrestrial part of the hydrological cycle to the atmosphere is neglected, which may result in significant errors (Seneviratne et al. 2010).

In modelling the land surface energy balance, the representation of the soil moisture in particular is found to be crucial (Sellers and Hall 1992). Significant errors may arise if the spatial variability is not included, e.g. by use of simple averaging (Wood 1997). The spatial variability of soil moisture can be modelled in different ways. Giorgi and Avissar (1997) provided a description of different approaches of including surface heterogeneities in atmospheric models. In Kollet and Maxwell (2008) the land surface influence on surface fluxes is further investigated documenting a distinct correlation between groundwater depth and evapotranspiration.

The effect of the feedback from soil moisture and land surface processes on the atmosphere has been studied in a range of studies. Miguez-Macho et al. (2007) showed that the inclusion of groundwater can lead to substantially wetter soils in some valley and coastal regions using the RAMS-hydro which is a nonhydrostatic regional climate model including a groundwater component. Using the same model setup, Anyah et al. (2008) showed that for regions where the groundwater table produces wetter soils a direct improvement in the reproduction of evapotranspiration is seen for dryer areas in North America. The influence of land surface temperatures and spatio-temporal soil moisture distribution on the simulation of sensible and latent heat fluxes is highlighted by Zeng et al. (2003) using the RegCM2 regional climate model over Eastern China.

To account for the feedback between the land surface and the atmosphere coupled hydrological-atmospheric models have emerged. Yuan et al. (2008) implemented a simple groundwater model into the regional climate model RegCM3. They found that the dynamical groundwater table affected the surface fluxes and hereby the boundary layers, the location of precipitation and the wind. Maxwell et al. (2011) coupled ParFlow to the Advanced Weather and Research model WRF (Skamarock et al. 2008) and highlighted the influence of soil moisture in predicting the boundary wind layer. Overgaard et al. (2007) investigated the coupling of MIKE SHE (Graham and Butts 2005) to ARPS (Xue et al. 2000; 2001). In a hypothetical land use change study they found significant differences between the results of the coupled model system and the traditional oneway approach, where MIKE SHE was forced by ARPS. York et al. (2002) illustrated how a future change in groundwater may affect the future evapotranspiration; e.g. long continuous drying, like the 1930 dust bowl, might lower the groundwater table making less water available for evapotranspiration. York et al. (2002) also found that groundwater dynamics had to be considered for proper long term simulation of droughts. 
Among regional climate models (RCMs) a general bias related to the representation of surface processes was found within the ENSEMBLES project (van der Linden and Mitchell 2009). In simulations forced by the ERA-40 reanalysis many models showed an increased warm bias with increasing monthly mean temperatures (Boberg and Christensen 2012; Christensen et al. 2008). A similar warm bias was reported within the PRUDENCE project (Jacob et al. 2007). Christensen et al. (2008) explained this bias in terms of the simulated soils in the warm dry summer months which become too dry and thereby created unrealistically high sensible heat fluxes. They argued that this is because of the simplistic land surface representation in many RCMs. Arguably, coupling the RCMs to a hydrological model may reduce the temperature bias as the hydrological model provides a comprehensive and perhaps more accurate surface flux calculation than the generally simpler schemes typically embedded in a RCM.

The objectives of the present study are; 1) to analyse the importance of including groundwater dynamics in the estimation of land surface - atmosphere feedbacks, and;2) to evaluate potential benefits and challenges in the hydrology-land surface response when applying a fully coupled climate-hydrological model with an advanced land surface flux scheme. The FIFE area in Kansas, USA, is used as a test case for evaluating the effects of replacing the land surface scheme in HIRHAM regional climate model with a high resolution MIKE SHE based hydrology and land surface model including groundwater.

\section{Methodology}

Observations /study area

During the First International Satellite Land Surface Climatological Project (ISLSCP) Field Experiment (FIFE) (Sellers et al. 1992) an area of 15 x $15 \mathrm{~km}^{2}$ near Manhattan in Kansas, USA, was intensively monitored. The FIFE data set consists of a high number of meteorological station, soil and vegetation data and is therefore ideal for testing land surface models (Sellers et al. 1992). The FIFE land surface can be characterized as tallgrass prairie at an elevation between $350-450$ m.a.s. The data used in the present study is monitored from May $26^{\text {th }}$ to October $16^{\text {th }}$ in 1987 , with four intensive field campaigns of roughly two weeks duration (Betts and Ball, 1998). The soils are all either silty loam or silty clay loam (Huemmrich and Levine 1994; Kanemasu 1994). Below the soils there are layers of limestone and shale. Since FIFE is defined as a square and not a hydrological catchment, measurements of total discharge were not applicable.

Discharge is therefore only measured in the $12 \mathrm{~km}^{2}$ King's Creek catchment at 15 min intervals, when flow rates exceeded $3 \times 10^{-4} \mathrm{~m}^{3} / \mathrm{s}$ (Wood 1994).

\section{Models}

MIKE SHE (Graham and Butts 2005) is an integrated distributed numerical modelling system. In this study the model is configured using the modules for overland flow (2D diffusive wave), unsaturated flow (1D Richards' equation), saturated groundwater flow (3D Darcy equation) and evapotranspiration (two-layer Shuttleworth and Wallace scheme; Overgaard 2005).

HIRHAM is a regional climate model (Christensen et al. 2006). It consists of the dynamical core of the synoptic scale weather forecast model HIRLAM (Undén et al. 2002) where the physical parameterisation 
schemes are replaced by those from the global circulation model ECHAM (Roeckner et al. 2003). The land surface model has five layers for calculation of soil temperature and the water budget is formulated with four reservoirs: snow intercepted by canopy, snow at surface, rainwater intercepted by canopy and soil water. For the coupled simulations MIKE SHE and HIRHAM are linked using the OpenMI software (Open Modelling Interface) (Gregersen et al. 2007) facilitating data transfer across the operational platforms of Windows and a Linux high performance parallel computation system (HPC). The coupling approach is described in Butts et al. (2014). OpenMI also handles the data exchange timing, variable definitions, unit conversions and spatial interpolation. The coupling is performed with each model operating at dedicated spatial scales: The RCM covers about half of the USA (Fig. 1), while the hydrological model only covers the $15 \times 15 \mathrm{~km}^{2}$ FIFE area corresponding roughly to a single RCM grid. Outside the FIFE area, the land surface processes in the coupled model are based on the HIRHAM scheme. Data are exchanged between the two models every hour.

\section{Hydrological model parameterisation and data processing}

The MIKE SHE setup in this study is an extension of the setup described in Rasmussen et al. (2012a), where modules for saturated groundwater flow and streamflow are now included. Parameterisation of the unsaturated zone is taken directly from field data from FIFE and literature (Rasmussen et al. 2012a). In contrast, no direct data are available for parameterisation of the saturated zone and streams. Therefore, these modules are parameterised by a combination of default or literature values or literature and calibration. Calibration has been performed against discharge measurements of King's Creek (Fig. 1). When running MIKE SHE in uncoupled mode the atmospheric driving data are station based from the FIFE data base consisting of ten meteorological stations with half-hourly collection (Dabberdt 1994). The classification of vegetation is based on Davis et al. (1992). The classification includes a combination of either burned or unburned and either upland, bottomland, moderate slope or steep slope. Vertically, the soils are parameterised based on the five soil profile analyses in the FIFE data base (Huemmrich and Levine 1994; Kanemasu 1994). Horizontally, the classification is based on the soil map provided in the FIFE data base, where each type has been related to one of the five soil profile, a mean soil profile or a coarser texture unknown profile (Rasmussen et al. 2012a). The unsaturated zone is initialized with soil moisture at equilibrium pressure; i.e. field capacity at the surface and full saturation at the top of the groundwater table. Layers of near-horizontal and relatively impermeable shale and thin limestone layers are underlying the surface soil (Davis et al. 1992). The hydraulic conductivity of the limestone is in the range $10^{-8}-10^{-3} \mathrm{~m} / \mathrm{s}$ (Macpherson 1996). The shale and limestone layers are assumed to be more fractured and porous near the surface, because of weathering. Therefore, the transport of water is assumed to only be important in the top of the shale and limestone layers. The aquifer is represented by a 2D model with the impermeable bed located at $10 \mathrm{~m}$ below the surface and a calibrated hydraulic conductivity of $5 \times 10^{-6} \mathrm{~m} / \mathrm{s}$. Rapid localised run-off in sub-grid scale creeks and gullies on the hills and slope are represented conceptually as drains. The drain level is $1 \mathrm{~m}$ below the surface and the drain constant is calibrated to $10^{-5} \mathrm{~s}^{-1}$. The drains are activated, 
when the groundwater table exceeds this level, and the water is then routed to the nearest stream based on the topography.

The locations of streams are derived from a digital elevation model at a $25 \mathrm{~m}$ grid (Strebel et al. 1994). In the King's Creek catchment streams have been inserted in the model for reaches with catchments larger than 1.5 $\mathrm{km}^{2}$, while this limit has been set to $10 \mathrm{~km}^{2}$ for the remaining part of the FIFE area. Idealised V-shape cross sections are defined along the streams and interaction with the aquifer is only controlled by the hydraulic conductivity of the aquifer.

The location of the groundwater table is unknown. The initial groundwater head conditions for the FIFE observation period have therefore been simulated by running the model for a sufficiently long warm-up period so that the given initial conditions do not influence the simulation results. This was achieved by three looped simulations of the period January $1^{\text {st }} 1985$ to December $31^{\text {st }} 1987$, each time saving the groundwater heads which were then used as an initial condition for the following run.

\section{HIRHAM setup}

HIRHAM (version 5; Christensen et al. 2006) is run over a domain covering the central US, forced by ERA40 reanalysis data (Uppala et al. 2005). The domain is 122 by 122 cells with a resolution of 0.125 degrees and 31 vertical levels (Fig. 1). HIRHAM uses a rotated longitude/latitude model grid. The origin in this setup is located at FIFE Lon. -96.5 Lat. 39.0. The HIRHAM simulation is started on January $1^{\text {st }} 1987$, yielding five month of spin up. In the coupling HIRHAM is started from an uncoupled restart file on May $1^{\text {st }}$.

\section{Experimental setup}

Five model runs were performed:

- Run "MSHE-UZ-OBS" is taken from Rasmussen et al. (2012a). This MIKE SHE run represents a distributed 1D unsaturated zone (UZ) setup with a uniform stationary groundwater table at $3 \mathrm{~m}$ depth and distributed meteorological forcings, soils, vegetation and overland flow. The grid resolution is $60 \mathrm{~m}$. The simulation starts at May $1^{\text {st }} 1987$.

- Run "MSHE-SZ-OBS" includes streamflow modelling and the saturated zone (SZ) as a single aquifer with uniform properties. The simulation is started at May $1^{\text {st }} 1987$. The initial groundwater table is taken from the final warm up run at May $1^{\text {st }} 1987$.

- Run "MSHE-SZ-HH" is identical to MSHE-SZ-OBS but the simulated precipitation input from HIRHAM-STD (see below) is used. This allows a direct comparison between evapotranspiration schemes based on the same input.

- Run "HIRHAM-STD" is a HIRHAM simulation with its own land surface model. The simulation is started on January $1^{\text {st }} 1987$.

- Run "HIRHAM-MSHE" is a coupled run of HIRHAM and MIKE SHE (including groundwater and therefore coupling from the groundwater to the atmosphere over the FIFE area). The simulation is started May $1^{\text {st }} 1987$ from an uncoupled restart file of the HIRHAM-STD run and groundwater table as for MSHE-SZ-OBS and MSHE-SZ-HH. 


\section{Results}

Groundwater conditions and the influence of evapotranspiration and soil moisture

A direct calibration of the groundwater model was not possible, since there are no observed groundwater head data. The data providing most relevant information on groundwater conditions are therefore the baseflow recession parts of the discharge hydrograph at King's Creek (Fig. 2). The location of King's Creek and the discharge station is seen in Figure 1. The simulated discharge corresponds well to the temporal pattern and magnitude of the observations and the recession parts of the simulated hydrograph have largely similar shape as in the observed hydrograph. The similar shape of the hydrograph recessions indicates that the baseflow conditions, and hence the overall stream-aquifer interactions, are represented by the model. A perfect match in the timing of peaks cannot be expected in the warm up period (before May $1^{\text {st }} 1987$ ) as the precipitation input is not recorded within the catchment. In the FIFE period only one peak occurs at the end of May to mid-June.

Another indication of a plausible representation of groundwater by the model is the depth to the groundwater table, which is expected to be small in the bottom of the valleys and larger at the hill tops. Wood (1997) estimated the mean water table depth, based on the soil-topographic index of TOPLATS (Famiglietti and Wood 1994), to be $3.5 \mathrm{~m}$ in dry conditions and $2.0 \mathrm{~m}$ in wet conditions for the King's Creek catchment. The simulated depth to the groundwater table at the beginning of the FIFE period is seen in Figure 1 where the mean depth to the groundwater is $3.6 \mathrm{~m}$ for the whole FIFE area and $4.3 \mathrm{~m}$ for the King's Creek catchment. The simulated spatial distribution of depth to the groundwater is similar to the distribution of the soiltopographic index by Famiglietti and Wood (1994).

To illustrate the direct influence of the groundwater table on evapotranspiration, Figure 3 shows the simulated groundwater depths and evapotranspiration for three grid cells with the same vegetation, soil type and meteorological forcing. The three cells are selected as one of the highest and one of the lowest depths to groundwater table and one in between. The two cells with $\sim 2$ and $8 \mathrm{~m}$ depth to the groundwater table have similar evapotranspiration, while the cell with shallow groundwater table $(0-0.5 \mathrm{~m}$ below the surface) has a much larger evapotranspiration.

Figure 4 shows the depth to the groundwater table plotted against evapotranspiration on August $1^{\text {st }}$ for cells of two selected soil types for the MSHE-SZ-OBS simulation. The greatest spread in evapotranspiration, in cells with groundwater depth greater than $2 \mathrm{~m}$, is seen among the different classes of soil types; exemplified by the two shown soil types. The spread among vegetation types and meteorological stations is similar (not shown). The largest variation in the relationship between evapotranspiration and depth to groundwater is found among these soils for cells with groundwater depth less than $2 \mathrm{~m}$. Each point on Figure 4 has been coloured according to meteorological forcing. The different meteorological stations result in different levels of evapotranspiration at groundwater depth greater than $2 \mathrm{~m}$. Depending on the soil type, the depth where the groundwater table becomes unimportant varies from 1to $3 \mathrm{~m}$ (Soil type Silty loam to Silt - not shown). The results are to some extent influenced by the model setup: (i) as the drainage depth is located at $1 \mathrm{~m}$ below the surface in all grids, except at the bottomland vegetation in the low lying river valleys, the model may not be 
able to correctly simulate shallow groundwater table of less than $1 \mathrm{~m}$ depth; and (ii) the vertical discretization in the unsaturated zone has some effect on the calculated groundwater table.

Observed and simulated areal mean evapotranspiration and soil moisture changes in the unsaturated zone during the FIFE period are shown in Figure 5. The simulated evapotranspiration by MSHE-UZ-OBS and MSHE-SZ-OBS are largely similar, except for the dry period from mid-July to beginning of August, where MSHE-SZ-OBS has a higher evapotranspiration than MSHE-UZ-OBS. Also, the MSHE-UZ-OBS and MSHE-SZ-OBS simulations reproduce the observed evapotranspiration levels and temporal patterns whereas the MSHE-SZ-HH evapotranspiration is distinctly different. The soil moisture as simulated by MSHE-SZOBS is continuously drier than MSHE-UZ-OBS but otherwise comparable (Fig. 5). Most of this difference can be explained by the differing groundwater table forming the lower boundary condition for initialisation of the unsaturated zone with equilibrium pressure condition, which results in different initial soil moisture contents.

\section{HIRHAM simulations and the effect of the land surface}

The influence of land surface scheme on the simulation of six meteorological variables is shown in figure 6 . This compares the output from HIRHAM-STD and HIRHAM-MSHE with observations for the RCM grid cell covering $72 \%$ of the FIFE area. For the entire period there is generally a reasonable match between simulations and observations. Some exceptions include overestimation of air temperature and discrepancies in incoming shortwave radiation. These are affected by differences in cloud cover between simulations and observations where spatial scale issues and cell averaging have a large effect. For the single HIRHAM cell over the FIFE area precipitation does not occur on the same days as observed and is generally overestimated, most notably for the HIRHAM-MSHE simulation. From May $1^{\text {st }}$ to Oct $16^{\text {th }}$ the observed precipitation is $495 \mathrm{~mm}$ whereas the HIRHAM-STD and HIRHAM-MSHE levels are 684 and $1523 \mathrm{~mm}$ respectively. The largest HIRHAM-MSHE overestimations occur during the first half of the FIFE period. This geographical region is subject to highly dynamic convective precipitation with a high degree of variability on spatial scales compared to the HIRHAM grid cell resolution of the present study. To illustrate this, precipitation output from the 5 RCM cells surrounding the FIFE grid cell (11x11 cell output size; 150 $\mathrm{km} \times 150 \mathrm{~km}$ area) are extracted and these vary between 420-1310 mm for HIRHAM-STD and 542-1777 $\mathrm{mm}$ for HIRHAM-MSHE.

The comparison between the uncoupled HIRHAM-STD and the coupled HIRHAM-MSHE shows that the difference between the two models is negligible for many meteorological variables, such as surface air pressure. This is not surprising, since the coupling is very localized, i.e. MIKE SHE is only replacing the HIRHAM-STD scheme in the local $15 \times 15 \mathrm{~km}^{2}$ FIFE area. However, for some variables such as air temperature and precipitation there are notable differences (Fig. 6).

\section{Effect of meteorological forcing and land surface scheme on evapotranspiration and soil moisture} The MSHE-SZ-HH simulated evapotranspiration show a distinctly different dynamics than the observation driven simulations (Fig. 5). This clearly shows the influence of precipitation on evapotranspiration. The 
simulated daily variations in evapotranspiration do not appear to match and the main variations appear related to precipitation events (Fig. 6). For MSHE-SZ-HH the highest precipitation events occur around 27 May - 2 June, 4-12 July and in mid-August. The general evapotranspiration level, and total period budget, is however reproduced with a sum of $531 \mathrm{~mm}$ compared to the observed $540 \mathrm{~mm}$ (Table 1). Similarly to the simulated evapotranspiration, MSHE-SZ-HH reflects positive soil moisture changes temporally related to precipitation events in, especially, early July and early August.

Figure 7 shows simulated evapotranspiration and soil moisture change of the unsaturated zone by MSHESZ-OBS, HIRHAM-STD and HIRHAM-MSHE. Firstly, it should be noted that the nature of the simulations resulted in substantial differences in precipitation input complicating the analysis (Table 1) and especially the HIRHAM-MSHE run is an outlier with approximately three times the observed precipitation during the period. These differences are also reflected in the evapotranspiration levels especially for June-July.

The differences in the MIKE SHE and HIRHAM land surface schemes is seen to have a substantial effect on evapotranspiration and soil moisture (Fig. 7 and Table 1): The precipitation input for MSHE-SZ-HH and HIRHAM-STD is the same and differences are therefore due to energy flux schemes and the complexity in hydrological processes, and in particular groundwater. Comparing the MSHE-SZ-HH and HIRHAM-STD evapotranspiration, the latter shows a more dynamical behaviour and general higher levels (531 and $586 \mathrm{~mm}$ respectively, table 1). In the dry period, from 13 July to 12 August, MSHE-SZ-HH more closely resembles the observations than HIRHAM-STD, where the evapotranspiration is generally higher. For soil moisture MSHE-SZ-HH and HIRHAM-STD are more similar except in the dry mid-summer period where HIRHAMSTD is depleted at a faster rate than MSHE-SZ-HH which also resembles the observations by having the same gradient. The high precipitation input in the HIRHAM-MSHE run is also reflected in overall higher evapotranspiration levels as well as peaks and the soil moisture change patterns resemble the HIRHAM-STD with variations related to differences in precipitation. The precipitation in HIRHAM-MSHE is around twice as high as in the HIRHAM-STD simulation, the runoff is nearly three times as high (Table 1) whereas the evapotranspiration is $1.3 \mathrm{~mm} / \mathrm{d}$ higher. Thus, a high intensity precipitation event causes increased runoff due to exceedance of infiltration capacity, whereas the soil moisture and evapotranspiration is less affected. In HIRHAM-MSHE the general levels of simulated evapotranspiration are higher than the MIKE SHE based simulations and equal to the HIRHAM-STD simulation at all groundwater depths as seen for 1 August in figure 8a. The MSHE-SZ-OBS and MSHE-SZ-HH evapotranspiration levels are generally comparable although the latter is higher for depths to the groundwater lower than app. $1.75 \mathrm{~m}$ and vice versa. The groundwater depth at which there is an influence on the evapotranspiration diminishes at levels of 0.5-3 m, and evapotranspiration reaches levels of 6-11 mm/day for the highest groundwater levels. All three simulations with distributed groundwater have a peak in groundwater depths at the intervals of $0.5-0.75 \mathrm{~m}$ or 0.75-1 $\mathrm{m}$ and there is a tendency for a positive correlation with precipitation amount input and share of lower groundwater depth grid cells (Fig. 8b).

\section{Discussion}


The present study shows results from simulation with two different land surface schemes, varying groundwater conditions and varying precipitation input. It is shown that enhancements in the representation of groundwater improve the simulation of evapotranspiration (Fig. 5) and, not unexpectedly, that precipitation amounts as well as timing is equally important to reproduce evapotranspiration (Fig. 5 and 7). However, the $178 \mathrm{~mm}$ difference between observed and simulated (HIRHAM-STD) precipitation input results in negligible differences in evapotranspiration where instead the unsaturated storage and river drainage is affected. Evidence of the potentially added value of coupling an RCM to a hydrological model, especially in dry periods where evapotranspiration substantially exceeds the net precipitation is seen. In the dry period within the FIFE experiment (mainly July and start August) HIRHAM-STD overestimates the evapotranspiration, implying that the soil moisture is not a limiting factor. In contrast, MSHE-SZ-HH, using the same precipitation input, simulates a drying of the soil and a reduction in the evapotranspiration (Fig. 7). The MSHE-SZ-OBS simulation, including groundwater, shows how evapotranspiration is high during the dry period for the cells with shallow groundwater table (Fig. 3).The MSHE-UZ-OBS simulation with uniform groundwater table at $3 \mathrm{~m}$ does not have shallow groundwater in the valleys and cannot maintain evapotranspiration during the dry out period (Fig. 5), while it is able to represent evapotranspiration in areas with a groundwater depth $>2 \mathrm{~m}$ (Fig. 8a). The simulations suggest that the area, where groundwater is less than $2 \mathrm{~m}$ deep, represents $35 \%$ of the total FIFE area at the end of the dry out period. Resolving the groundwater conditions adequately requires a hydrological model with fine resolution, depending on the topography of the catchment and especially the width of the river valleys. Typically, the soil and vegetation may differ in the valleys compared to the surroundings. Therefore, a finer spatial resolution of the valleys may be required to simulate the effects of different soils (like Fig. 4). In our case grid sizes in the order of 60-240 $\mathrm{m}$ are required (Rasmussen et al. 2012a). If, however, the effect of shallow groundwater is disregarded, the hydrological model can be run at much coarser resolution as long as the variation in vegetation and soil types are preserved (Rasmussen et al. 2012a). The mosaic approach used here for modelling the land surface with a high resolution hydrological model is computationally demanding. Running a coupled climate simulation with MIKE SHE at $60 \mathrm{~m}$ resolution for the whole HIRHAM domain is not feasible with the current computational capacity and would also require extensive validation of the MIKE SHE model. The local coupling approach allows the high resolution hydrological model to be applied only for areas of particular importance for the land surface atmosphere interaction or for areas where the hydrological effects of climate change are of interest. Computationally more efficient, statistical methods exist for handling subgrid variability in soil, vegetation, topography and groundwater depth, but they do not allow changes in groundwater table due to e.g. climate change.

This study found differences in daily evapotranspiration rates of $\sim 6 \mathrm{~mm}$ /day in the dry period between two similar cells with groundwater tables in 0.5 and $2 \mathrm{~m}$ depth, respectively. Likewise, Kollet and Maxwell (2008) and Maxwell and Kollet (2008) found strong correlation between depth to groundwater and evapotranspiration at groundwater depths, which they term the critical zone. In their study of the Little Washita in Oklahoma the critical zone is between 1 and $5 \mathrm{~m}$ below the surface, while the corresponding depths in our results are between 1 and $3 \mathrm{~m}$ below the surface. Considering that the two studies are from 
different locations with differences in soils and vegetation, model codes with different conceptualisations of unsaturated zone flows and root water uptake and that none of the studies are validated against field data, our results support the overall conclusion of Kollet and Maxwell (2008) and Maxwell and Kollet (2008). This finding emphasizes the potential of using a fully coupled system for proper climate simulations as the accumulated difference in evapotranspiration rates under more extreme hydrological conditions may be large and hence determine whether the model will be able to represent a hydraulic drought or not. In relation to the generally acknowledged warm bias in warm months among RCMs over Europe (Christensen et al. 2008), our study shows that inclusion of groundwater in a hydrological model coupled to a RCM can maintain a high evapotranspiration during dry summers; and, hence, better partition the available energy between sensible and latent heat fluxes. In view of this, coupled climate-hydrological models have a potential for improving the simulations of soil surface temperature. In this study it is found that the coupled HIRHAM-MSHE model has a slightly different mean bias of the simulated $2 \mathrm{~m}$ air temperature compared to the default HIRHAM-STD model, but none of the two models are found to be significantly better in their overall fit to the temperature observations. For the present study however, the precipitation bias for the coupled cell is clearly affected by the coupling which leads to a different water balance for the coupled area and, hence, surface energy balance.

The coupled precipitation bias is likely to be caused by either: i) climate model variability as induced by the perturbation from introducing the coupling, ii) effect of land surface feedback or iii) numerical shock from overwriting HIRHAM-STD internal variable which feed into other physical equations and parameterisations. It is outside the scope of the present study to decide which combination of these, maybe in combination, is the most likely cause. Instead, the coupled simulation is simply used as an additional method of forcing the land surface calculations. Minor perturbations (or change in the model setup like the domain or resolution) are however known to cause two RCM simulations to differ even though the RCM setups otherwise are identical (Miguez-Macho et al. 2004; Rasmussen et al. 2012b; Larsen et al. 2014). Also, the region of the study in Kansas, USA, has previously shown high degrees of spatio-temporal variability related to convective precipitation (Rasmussen et al. 2012b). Another use of the same HIRHAM - MIKE SHE coupling is seen in Butts et al (2014) and Larsen et al. (2014) covering the $2500 \mathrm{~km}^{2}$ Skjern River catchment in Denmark featuring multiple one-year model runs and coupling 23 HIRHAM cells in $11 \mathrm{~km}$ resolution. As for the present, Larsen et al. (2014) found poorer precipitation results for coupled simulations as compared to uncoupled results when assessing hourly to daily dynamics. However, longer term precipitation was improved which more recently was further emphasized for a six-year simulation where the coupled precipitation bias was significantly diminished compared to uncoupled (Larsen 2014).

\section{Conclusions}

Our results show that evapotranspiration is highly dependent on the depth to the groundwater, especially during dry periods, and that a correct groundwater representation therefore is important. Further, and not to much surprise, the timing in precipitation input is highly influencing the timing of evapotranspiration, which is therefore highly dependent on the input source to obtain exact daily dynamics. Longer term 
evapotranspiration as reflected here by the 144 day simulation period is simulated equally well using a precipitation input amount of additional 36\%. The HIRHAM-STD evapotranspiration compares to observed data with only an $8.5 \%$ error, but in the dry period the evapotranspiration is too high, because it is not limited by the drier soil. This could be due to the wet bias of the RCM in the preceding period but may be caused by surface parameters that are not well adjusted to the local surface conditions. By the coupling the wet bias is even higher, which further change the water and energy balance from the observed. The hydrological model in contrast shows a reduction in evapotranspiration with soil moisture in the drying period, as expected. With this study improved results were obtained by improving the detail and process range in the land surface and groundwater hydrology and energy balance. The potential of coupling an RCM and a more complex hydrology model has therefore been demonstrated under the conditions found in the central USA. Additional studies where the catchment size and the simulation period are increased would further highlight the true benefits of the coupled model setup in the present region as has already been done in a study over a Danish catchment (Larsen et al. 2014).

\section{Acknowledgements}

The study was funded by a grant from the Danish Strategic Research Council for the project HYdrological Modelling for Assessing Climate Change Impacts at differeNT Scales (HYACINTS

- www.hyacints.dk) under Contract No: DSF-EnMi 2104-07-0008.

\section{References}

Anyah RO, Weaver CP, Miguez-Macho G, Fan Y, Robock A (2008) Incorporating water table dynamics in climate modeling: 3. Simulated groundwater influence on coupled land-atmosphere variability. Journal of Geophysical Research. doi: 10.1029/2007JD009087

Betts AK, Ball JH (1998) FIFE Surface Climate and Site-Average Dataset 1987-89. J Atmos Sci 55:1091-1108. doi: 10.1175/1520-0469(1998)055<1091:FSCASA>2.0.CO;2

Boberg F, Christensen JH (2012) Overestimation of Mediterranean summer temperature projections due to model deficiencies. Nature Climate Change 2:433-436. doi: 10.1038/nclimate1454

Butts M, Drews M, Larsen MAD, Lerer S, Rasmussen SH, Grooss J, Overgaard J, Refsgaard JC, Christensen OB, Christensen JH (2014) Embedding complex hydrology in the regional climate system - Dynamic coupling across different modelling domains. Advances in Water Resources 74:166-184. doi: 10.1016/j.advwatres.2014.09.004

Christensen OB, Drews M, Christensen JH, Dethloff K, Ketelsen K, Hebestadt I, Rinke A (2006) The HIRHAM Regional Climate Model. Version 5. DMI Technical Report 06-17. Available from DMI, Lyngbyvej 100, Copenhagen $\varnothing$, Denmark

Christensen JH, Boberg F, Christensen OB, Lucas-Picher P (2008) On the need for bias correction of regional climate change projections of temperature and precipitation. Geophysical Research Letters. doi: 10.1029/2008GL035694 
Dabberdt WF (1994) Automated met station data FIFE. http://www.daac.ornl.gov. Accessed 20 February 2015. Also published in Strebel et al. (1994)

Davis FW, Schimel DS, Friedl MA, Michaelsen JC, Kittel TGF, Dubayah R, Dozier J (1992) Covariance of biophysical data with digital topographic and land use maps over the FIFE site. J Geophys Res 97:19009-19021. doi:

10.1029/92JD01345

Famiglietti JS, Wood EF (1994) Multiscale modeling of spatially variable water and energy balance processes. Water Resour Res 30:3061-3078. doi: 10.1029/94WR01498

Giorgi F, Avissar R (1997) Representation of heterogeneity effects in Earth system modeling: Experience from land surface modeling. Rev Geophys 35:413-437. doi: 10.1029/97RG01754

Graham LP, Andréasson J, Carlsson B (2007) Assessing climate change impacts on hydrology from an ensemble of regional climate models, model scales and linking methods-a case study on the Lule River basin. Climatic Change 81:293-307.

Graham DN, Butts MB (2005) Flexible, integrated watershed modelling with MIKE SHE, in: Watershed Models (Eds VP Singh \& DK Frevert). CRC Press, Boca Raton, Florida, USA, 245-272, ISBN: 0849336090

Gregersen JB, Gijsbers PJA, Westen SJP (2007) OpenMI: Open modelling interface. Journal of Hydroinformatics 9:175. doi: 10.2166/hydro.2007.023

Huemmrich FK, Levine E (1994) Soil survey reference FIFE. Data set available on-line http://www.daac.ornl.gov. Oak Ridge National Laboratory Distributed Active Archive Center, Oak Ridge, Tennessee, U.S.A. Accessed 20 February 2015. Also published in Strebel et al. (1994)

Jacob D, Bärring L, Christensen OB, Christensen JH, de Castro M, Déqué M, Giorgi F, Hagemann S, Hirschi M, Jones R, Kjellström E, Lenderink G, Rockel B, Sánchez E, Schär C, Seneviratne SI, Somot S, van Ulden A, van den Hurk B (2007) An inter-comparison of regional climate models for Europe: model performance in present-day climate. Climatic Change 81:31-52. doi: 10.1007/s10584-006-9213-4

Kanemasu ET (1994) Soil hydraulic conductivity data FIFE. Data set available on-line http://www.daac.ornl.gov. Oak Ridge National Laboratory Distributed Active Archive Center, Oak Ridge, Tennessee, U.S.A. Accessed 20 February 2015. Also published in Strebel et al. (1994)

Kollet SJ, Maxwell RM (2008) Capturing the influence of groundwater dynamics on land surface processes using an integrated, distributed watershed model. Water Resour Res 44:W02402. doi: 10.1029/2007WR006004

Larsen MAD (2014) Integrated Climate and Hydrology Modelling - catchment scale coupling of a regional climate model and a hydrological Model. Presentation at the TERENO International Conference 2014, Oct 1, Bonn, Germany. 
Larsen MAD, Refsgaard JC, Drews M, Butts MB, Jensen KH, Christensen JH, Christensen OB (2014) Results from a full coupling of the HIRHAM regional climate model and the MIKE SHE hydrological model for a Danish catchment. Hydrology and Earth System Sciences 18:4733-4749. doi: 10.5194/hess-18-4733-2014

Macpherson GL (1996) Hydrogeology of thin limestones: the Konza Prairie Long-Term Ecological Research Site, Northeastern Kansas. Journal of Hydrology 186:191-228. doi: 10.1016/S0022-1694(96)03029-6

Maxwell RM, Kollet SJ (2008) Interdependence of groundwater dynamics and land-energy feedbacks under climate change. Nature Geoscience 1:665-669. doi: 10.1038/ngeo315

Maxwell RM, Lundquist JK, Mirocha JD, Smith SG, Woodward CS, Tompson AFB (2011) Development of a Coupled Groundwater-Atmosphere Model. Monthly Weather Review 139:96-116. doi: 10.1175/2010MWR3392.1

Miguez-Macho G, Stenchikov GL, Robock A (2004) Spectral nudging to eliminate the effects of domain position and geometry in regional climate model simulations. J Geophys Res 109:D13104. doi: 10.1029/2003JD004495

Miguez-Macho G, Fan Y, Weaver CP, Walko R, Robock A (2007) Incorporating water table dynamics in climate modeling: 2. Formulation, validation, and soil moisture simulation. J Geophys Res 112:D13108. doi:

10.1029/2006JD008112

Overgaard J (2005) Energy-based land-surface modelling: New opportunities in integrated hydrological modelling. PhD Thesis. Environment and Resources DTU, Technical University of Denmark

Overgaard J, Butts MB, Rosbjerg D (2007) Improved scenario prediction by using coupled hydrological and atmospheric models. Quantification and reduction of predictive uncertainty for sustainable water resources management 242-248, (eds Boegh E, Kunstmann H, Wagener T, Hall A, Bastidas L, Franks S, Gupta H, Rosbjerg D and Schaake J), IAHS, 313, 242-248

Rasmussen SH, Butts MB, Lerer SM, Refsgaard JC (2012a) Parameterisation and scaling of the land surface model for use in a coupled climate-hydrological model. Journal of Hydrology 426-427:63-78. doi: 10.1016/j.jhydrol.2012.01.014

Rasmussen SH, Christensen JH, Drews M, Gochis DJ, Refsgaard JC (2012b) Spatial-Scale Characteristics of Precipitation Simulated by Regional Climate Models and the Implications for Hydrological Modeling. Journal of Hydrometeorology 13:1817-1835. doi: 10.1175/JHM-D-12-07.1

Roeckner E, Bäuml G, Bonaventura L, Brokopf R, Esch M, Giorgetta M, Hagemann S, Kirchner I, Kornblueh L, Manzini E, Rhodin A, Schlese U, Schulzweida U, Tompkins A (2003) Part 1. Model description. The atmospheric general circulation model ECHAM5. Report no.349, Max-Planck-Institut für Meteorologie (MPI-M) 
Sellers PJ, Hall FG, Asrar G, Strebel DE, Murphy RE (1992) An overview of the First International Satellite Land Surface Climatology Project (ISLSCP) Field Experiment (FIFE). J Geophys Res 97:18345-18371. doi: 10.1029/92JD02111

Sellers PJ, Hall FG (1992) FIFE in 1992: Results, scientific gains, and future research directions. J Geophys Res 97:19091-19109. doi: 10.1029/92JD02173

Seneviratne SI, Corti T, Davin EL, Hirschi M, Jaeger EB, Lehner I, Orlowsky B, Teuling AJ (2010) Investigating soil moisture-climate interactions in a changing climate: A review. Earth-Science Reviews 99:125-161. doi:

10.1016/j.earscirev.2010.02.004

Shelton ML (2009) Hydroclimatology, perspectives and applications.Cambridge University Press.

Skamarock WC, Klemp JB, Dudhia J, Gill OD, Barker DM, Duda MG, Huang X, Wang W, Powers JG (2008) A Description of the Advanced Research WRF Version 3. NCAR Technical note

Strebel DE, Landis DR, Newcomer JA, Meeson BW, Goetz SJ, Agbu PA, McManus JMP, Huemmrich KF, van ElburgObler D and Nickeson JE (1994) Collected Data of the First ISLSCP Field Experiment, Vols. 1-5. CD-ROM. National Aeronautics and Space Administration, Goddard Space Flight Center, Greenbelt, Maryland, U.S.A. Available from Oak Ridge National Laboratory Distributed Active Archive Center, Oak Ridge, Tennessee, Accessed online 20 February 2015, U.S.A. http://www.daac.ornl.gov/

Undén P, Rontu L, Järvinen H, Lynch P, Calvo J, Cats G, Cuxart J, Eerola K, Fortelius C, Garcia-Moya JA, Jones C, Geert, Lenderlink G, Mcdonald A, Mcgrath R, Navascues B, Nielsen NW, Degaard V, Rodriguez E, Rummukainen M, Sattler K, Sass BH, Savijarvi H, Schreur BW, Sigg R, The H (2002) HIRLAM-5 Scientific Documentation.

Uppala SM, KÅllberg PW, Simmons AJ, Andrae U, Bechtold VDC, Fiorino M, Gibson JK, Haseler J, Hernandez A, Kelly GA, Li X, Onogi K, Saarinen S, Sokka N, Allan RP, Andersson E, Arpe K, Balmaseda MA, Beljaars ACM, Berg LVD, Bidlot J, Bormann N, Caires S, Chevallier F, Dethof A, Dragosavac M, Fisher M, Fuentes M, Hagemann S, Hólm E, Hoskins BJ, Isaksen L, Janssen P a. EM, Jenne R, Mcnally AP, Mahfouf J-F, Morcrette J-J, Rayner NA, Saunders RW, Simon P, Sterl A, Trenberth KE, Untch A, Vasiljevic D, Viterbo P, Woollen J (2005) The ERA-40 re-analysis. QJR Meteorol Soc 131:2961-3012. doi: 10.1256/qj.04.176

van der Linden P, Mitchell JFB (eds) (2009) Summary of research and results from the ENSEMBLES project. ENSEMBLES: climate change and its impacts. Met Office Hadley Centre, Exeter

van Roosmalen L, Christensen BSB, Sonnenborg TO (2007) Regional Differences in Climate Change Impacts on Groundwater and Stream Discharge in Denmark. Vadose Zone J, 6:554-571. doi: 10.2136/vzj2006.0093

Wood EF (1994) 15 Minute Stream Flow Data: USGS (FIFE). http://www.daac.ornl.gov. Accessed online 20 February 2015. Oak Ridge National Laboratory Distributed Active Archive Center, Oak Ridge, Tennessee, U.S.A. Also published in Strebel et al. (1994) 
542 Wood EF (1997) Effects of soil moisture aggregation on surface evaporative fluxes. J Hydrol, 190:397-412, doi:

安43 10.1016/S0022-1694(96)03135-6

Xue M, Droegemeier KK, Wong V (2000) The Advanced Regional Prediction System (ARPS) - A multi-scale nonhydrostatic atmospheric simulation and prediction model. Part I: Model dynamics and verification. Meteorol Atmos Phys 75:161-193. doi: 10.1007/s007030070003

Xue M, Droegemeier KK, Wong V, Shapiro A, Brewster K, Carr F, Weber D, Liu Y, Wang D (2001) The Advanced Regional Prediction System (ARPS) - A multi-scale nonhydrostatic atmospheric simulation and prediction tool. Part II: Model physics and applications. Meteorol Atmos Phys 76:143-165. doi: 10.1007/s007030170027

York JP, Person M, Gutowski WJ, Winter TC (2002) Putting aquifers into atmospheric simulation models: An example from the Mill Creek Watershed, northeastern Kansas. Advances in Water Resources 25:221-238.

Yuan X, Xie Z, Zheng J, Tian X, Yang Z (2008) Effects of water table dynamics on regional climate: A case study over east Asian monsoon area. J Geophys Res 113:D21112. doi: 10.1029/2008JD010180

Zeng X-M, Zhao M, Su B-K, Tang J-P, Zheng Y-Q, Zhang Y-J, Chen J (2003) Effects of the land-surface heterogeneities in temperature and moisture from the "combined approach" on regional climate: a sensitivity study. Global and Planetary Change 37:247-263. doi: 10.1016/S0921-8181(02)00209-6

\section{Tables}

Tbl. 1 Water balance at FIFE over the FIFE period May $26^{\text {th }}$ to October $16^{\text {th }} 1987$; accumulated $\mathrm{mm}$. The difference in precipitation between HIRHAM-STD and MSHE-SZ-HH (using HIRHAM-STD precipitation as input) is due to the extraction from the central HIRHAM cell ( $72 \%$ of the FIFE area) and the FIFE weighted mean respectively

\begin{tabular}{|l|rcrrrrr|}
\hline Simulation & Pre. & ET & UZ & SZ & $\begin{array}{r}\text { Drain to } \\
\text { River }\end{array}$ & $\begin{array}{r}\text { Drain to } \\
\text { boundary }\end{array}$ & Baseflow \\
\hline Obs. & 495 & 540 & $-91^{*}$ & - & 26 & - & - \\
MSHE-UZ-OBS & 495 & 508 & -53 & - & - & 35 & - \\
MSHE-SZ-OBS & 495 & 542 & -70 & -25 & 36 & 11 & 1 \\
MSHE-SZ-HH & 673 & 531 & -50 & 6 & 121 & 34 & 2 \\
HIRHAM-STD & 684 & 586 & -68 & - & 207 & - & - \\
HIRHAM-MSHE & 1523 & 756 & -74 & 62 & 620 & 158 & 2 \\
\hline
\end{tabular}

* Relative to May $30^{\text {th }}$ or $-41 \mathrm{~mm}$ assuming $50 \mathrm{~mm}$ on May $30^{\text {th }}$ as for Fig 2. 


\section{Figures}

Fig. 1 (a) HIRHAM model domain and location of the FIFE study area. (b) Depth to groundwater table, simulated at the beginning of the FIFE period May 1987 by the third warm up run. The black solid line is the King's Creek catchment with the discharge station at the black dot. Cell id labels of the three selected cells used in Fig 4 are shown to the right

Fig. 2 Discharge of King's Creek observed and simulated by MSHE-SZ-OBS (the third warm up run)

Fig. 3 Evapotranspiration and groundwater table at three selected grid cells of MSHE-SZ-OBS. All cells have the same vegetation type (Burned Bottomland), soil type (Florence-Benfield) and meteorological station (4439). The locations of the three grid cells are shown in Fig 1

Fig. 4 Groundwater depth against daily mean evapotranspiration simulated by MSHE-SZ-OBS for each cell within soil type Florence-Benfield and silty loam, respectively, at August $1^{\text {st }}$. Each point is coloured according to the meteorological station used for forcing

Fig. 5 Evapotranspiration and soil moisture change in the unsaturated zone: Observed and simulated by MSHE-UZ-OBS, MSHE-SZ-OBS and MSHE-SZ-HH. The values are mean levels over the FIFE area

Fig. 6 Atmospheric forcing simulated by HIRHAM-STD compared to FIFE observations and HIRHAMMSHE July $28^{\text {th }}$ to August $4^{\text {th }}$ for the one HIRHAM cell covering $72 \%$ of the FIFE area (upper panels). Daily precipitation as mean over the FIFE area for the full FIFE period with HIRHAM-MSHE precipitation levels in text for two days exceeding the y-axis limit (lower panel)

Fig. 7 Evapotranspiration and soil moisture change in the unsaturated zone simulated by MSHE-SZ-HH, HIRHAM-STD and HIRHAM-MSHE; area mean over the FIFE area

Fig. 8 (a) Groundwater depths against daily mean evapotranspiration simulated by the five simulations at August $1^{\text {st }}$; the last day in a dry period for all three precipitation sources in the study (observations, HIRHAM-STD and HIRHAM-MSHE). Solid lines are running mean over $0.25 \mathrm{~m}$ intervals of depths to the groundwater. The grey diamond is the mean evapotranspiration by MSHE-UZ-OBS where the groundwater is prescribed uniform at $3 \mathrm{~m}$ depth. The black diamond is the mean evapotranspiration by HIRHAM-STD that does not specify the groundwater depth. (b) Percentage of grid cells within each $0.25 \mathrm{~m}$ interval of depth to the groundwater. 


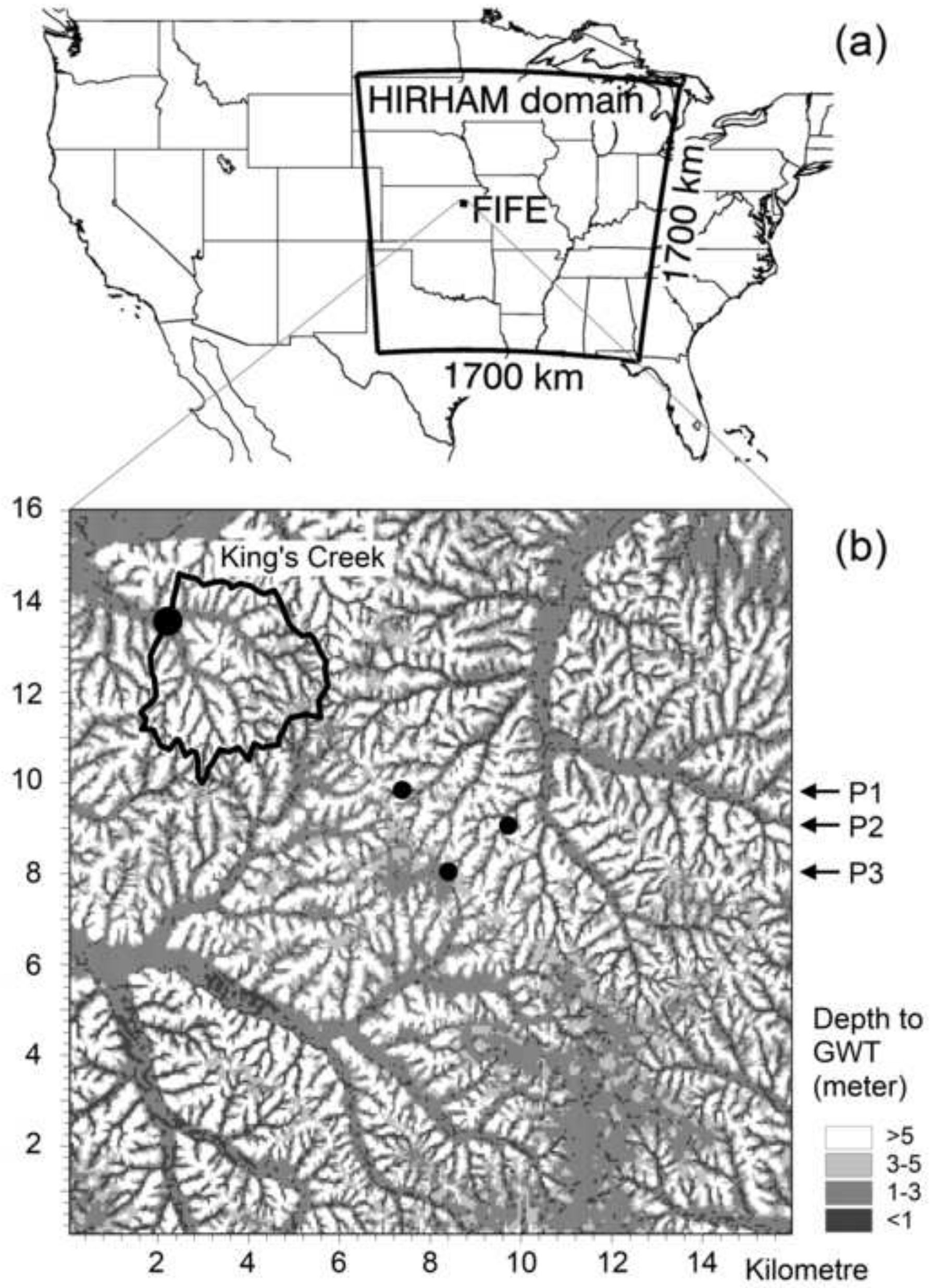




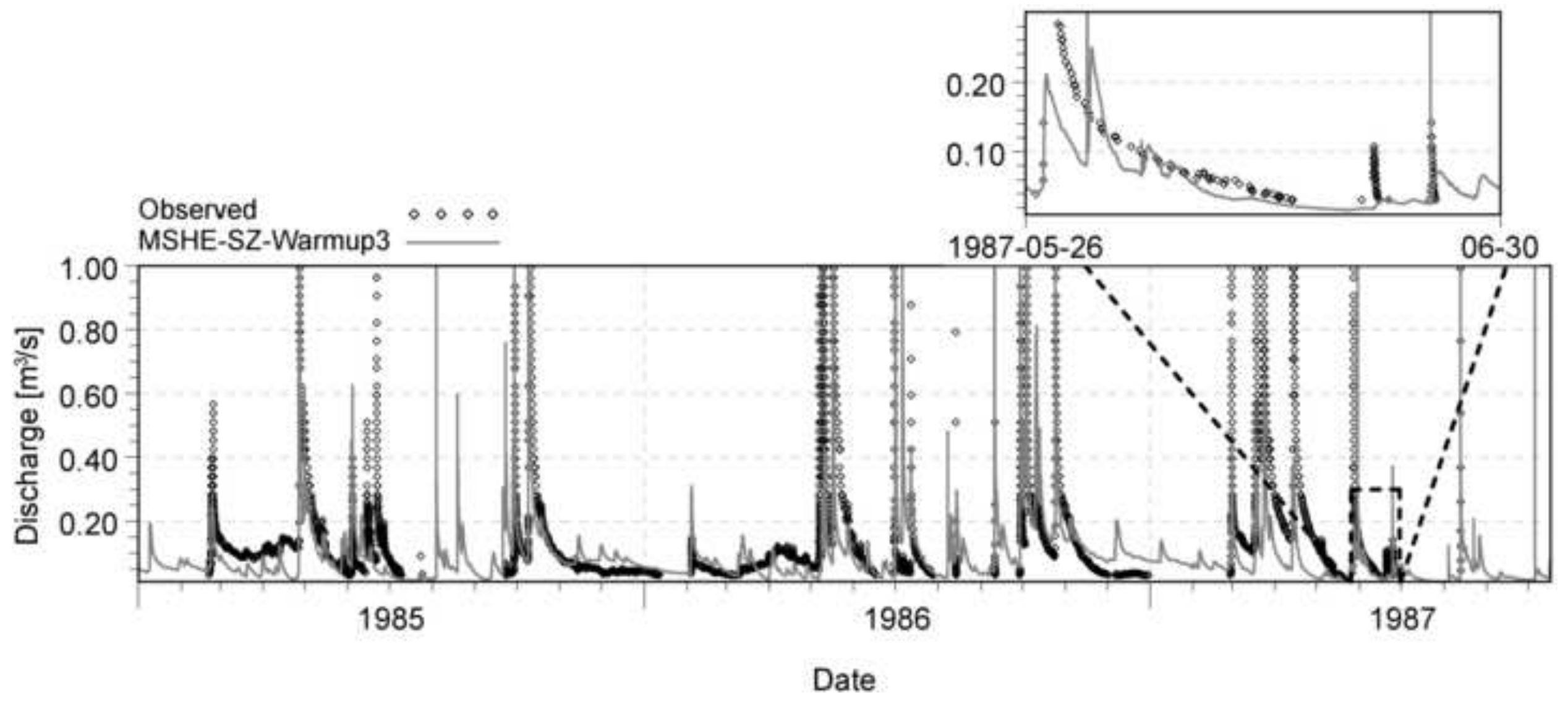


Eva. P1 [mm/day]

Eva. $\mathrm{P} 2$ [mm/day]

GWT P1 [m] - -

GWT P2 [m] -...-

Eva. P3 [mm/day]

- -

GWT P3 [m]

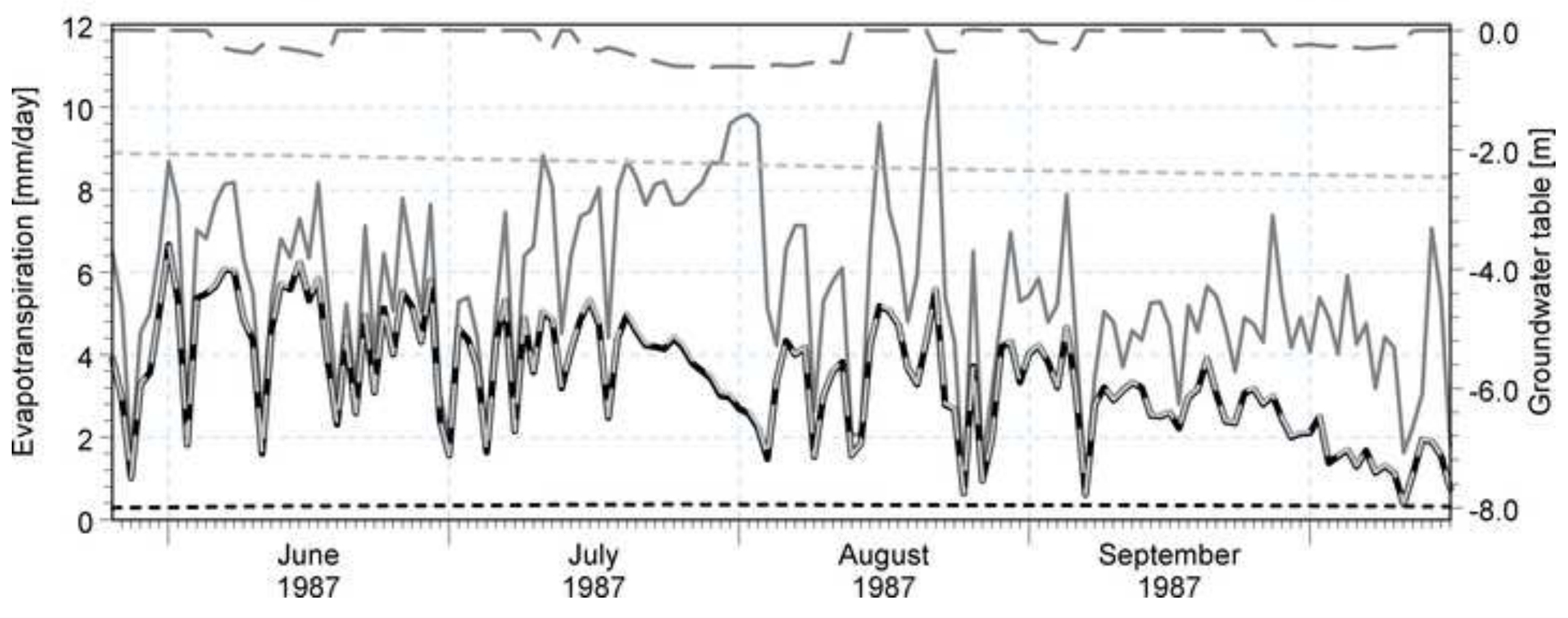


Florence-Benfield

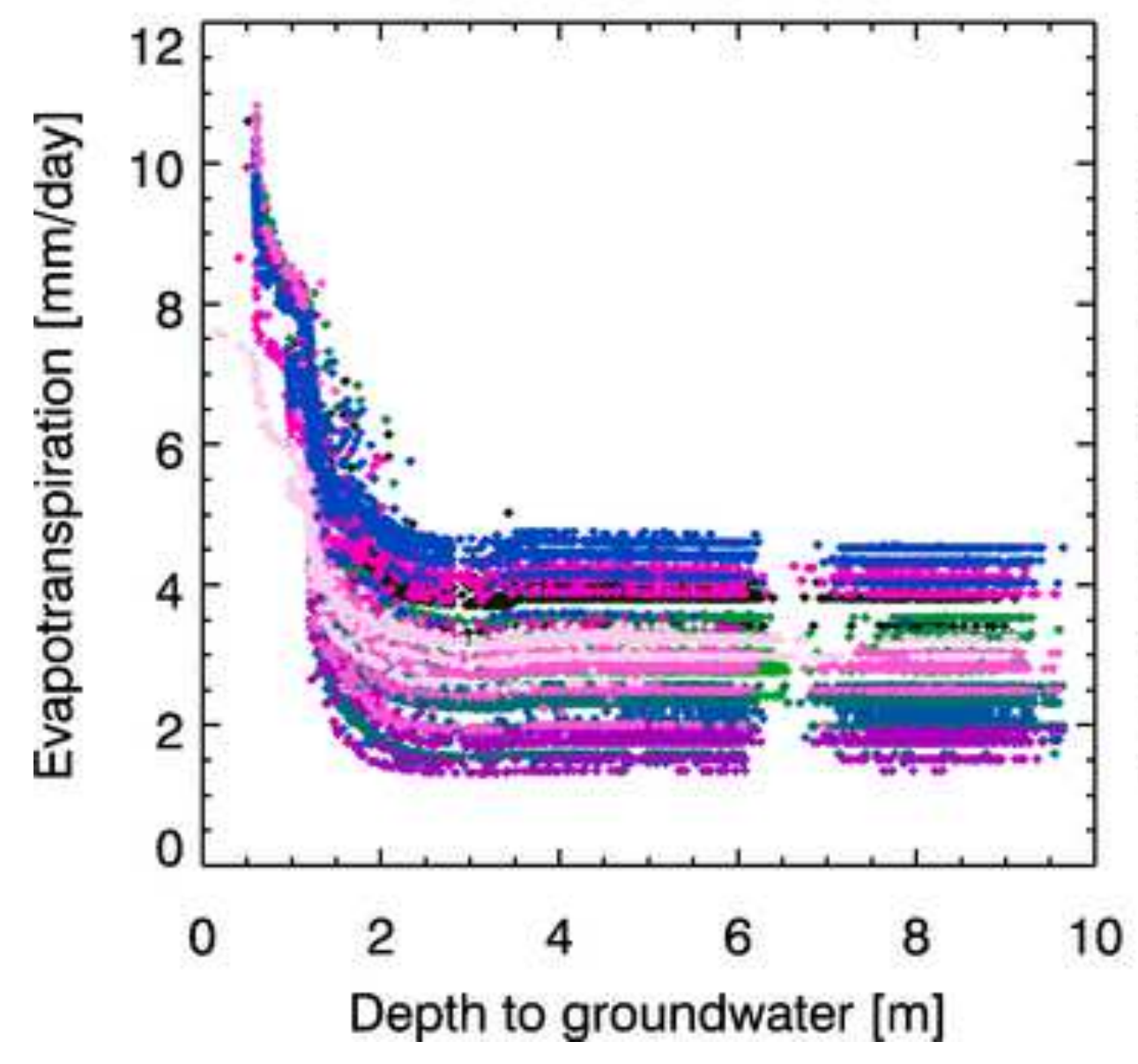

Silty Loam

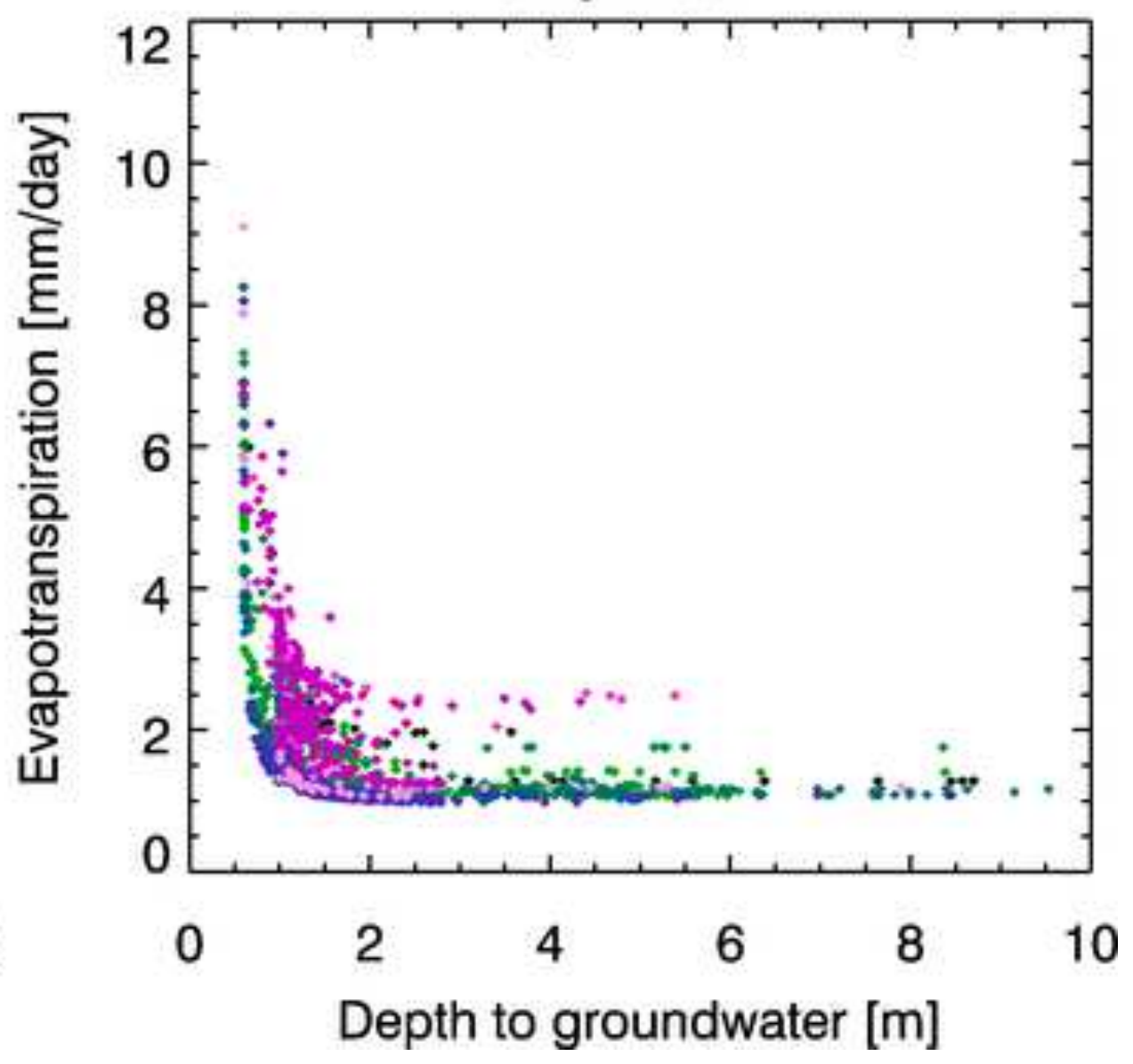


Eva. Obs. $\quad[\mathrm{mm} / \mathrm{day}] \ldots$

Eva. MSHE-UZ-OBS [ $\mathrm{mm} / \mathrm{day}]$ Eva. MSHE-SZ-OBS [mm/day] Eva. MSHE-SZ-HH [mm/day]
Soil mst. Obs.

Soil mst. MSHE-UZ-OBS [mm]

Soil mst. MSHE-SZ-OBS [mm]

Soil mst. MSHE-SZ-HH [mm]

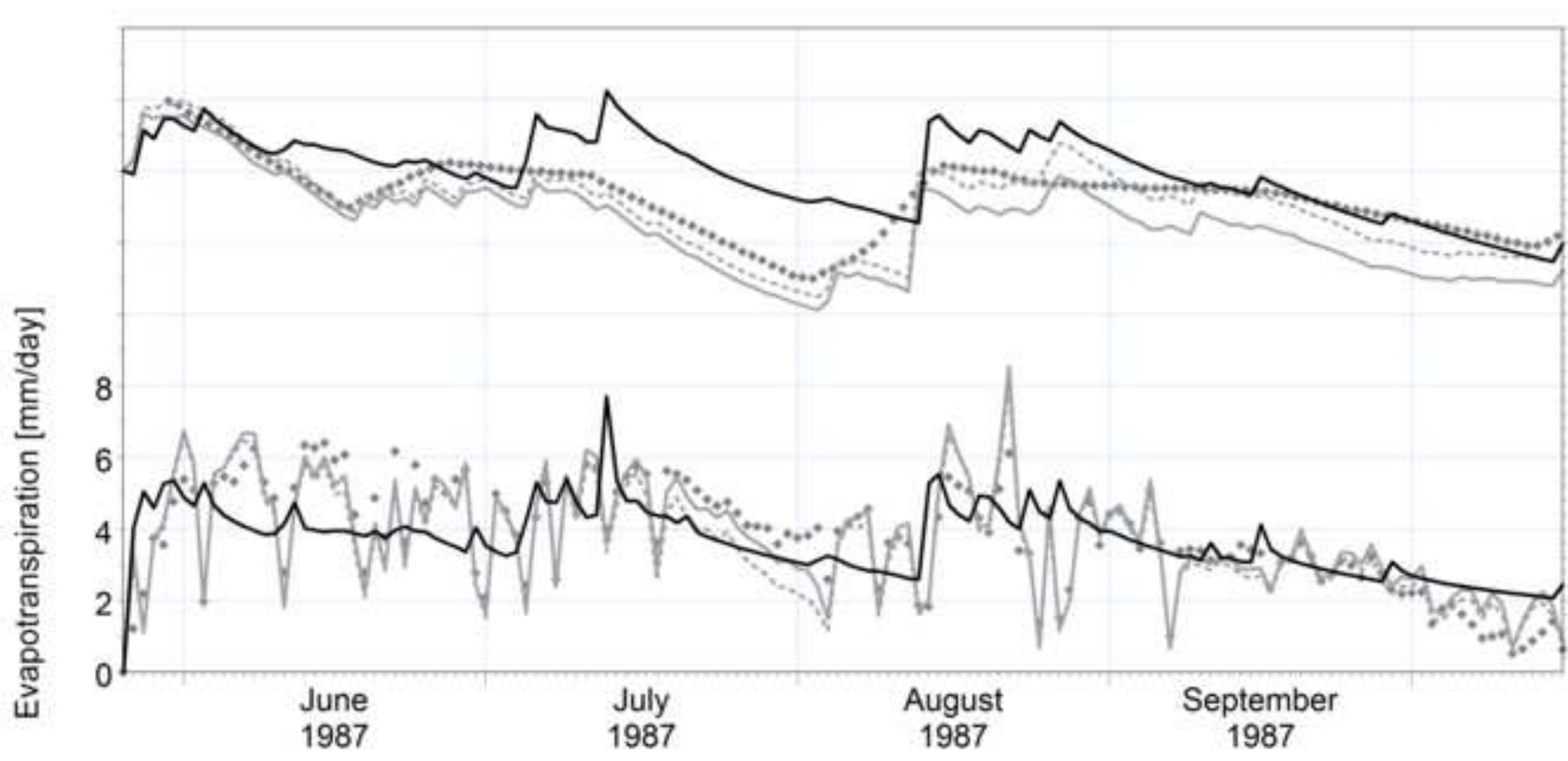



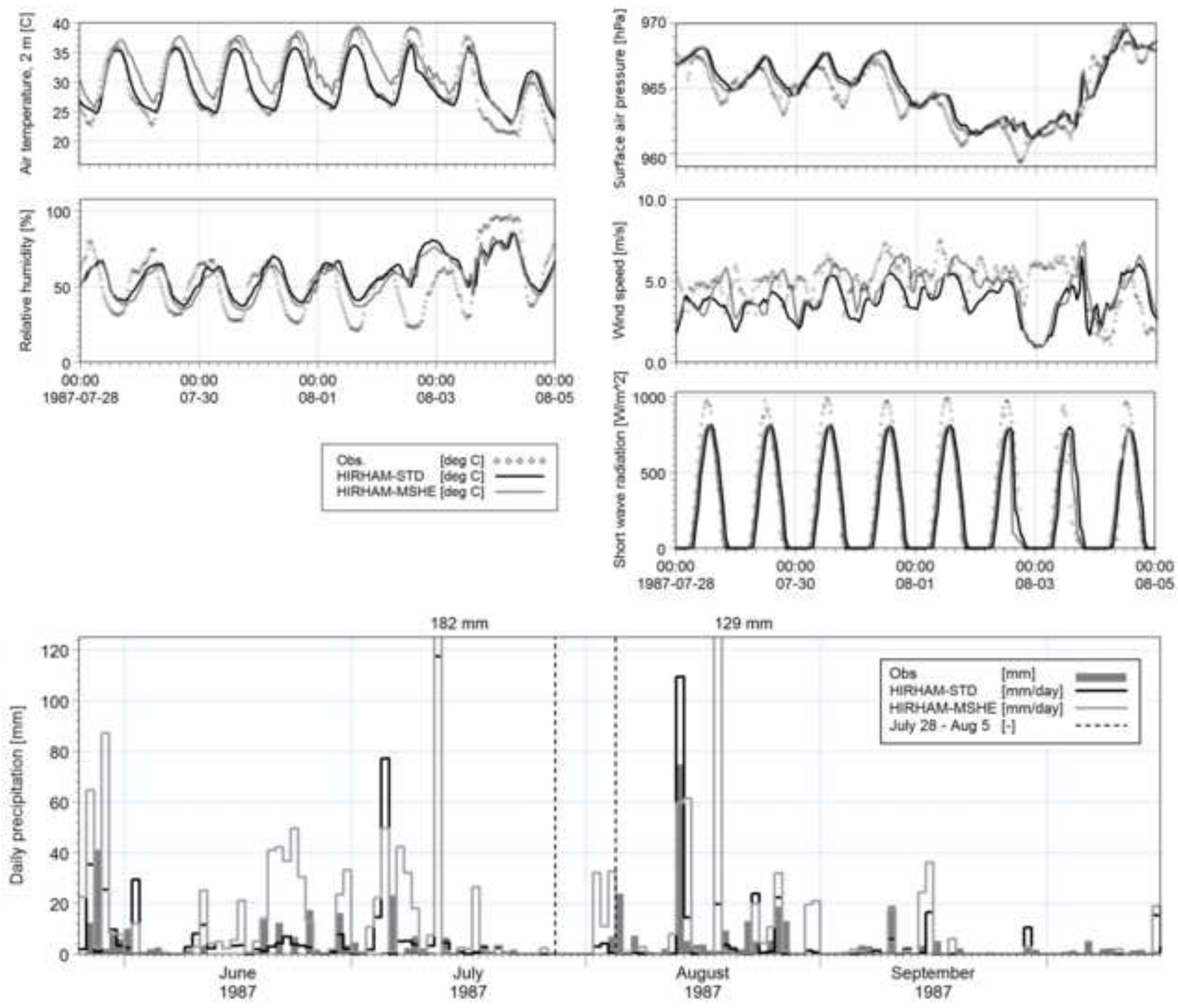

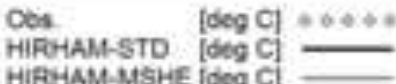
HIRUAM-MSHE [Dog C]

08-05 
$\begin{array}{ll}\text { Eva. Obs. } & {[\mathrm{mm} / \text { day }]} \\ \text { Eva. MSHE-SZ-HH } & {[\mathrm{mm} / \text { day }]} \\ \text { Eva. HIRHAM-STD } & {[\mathrm{mm} / \text { day }]}\end{array}$

Eva. HIRHAM-MSHE [mm/day]
Soil mstr. Obs.

Soil Mst. MSHE-SZ-HH

Soil Mst. HIRHAM-STD

Soll Mst. HIRHAM-MSHE [mm]
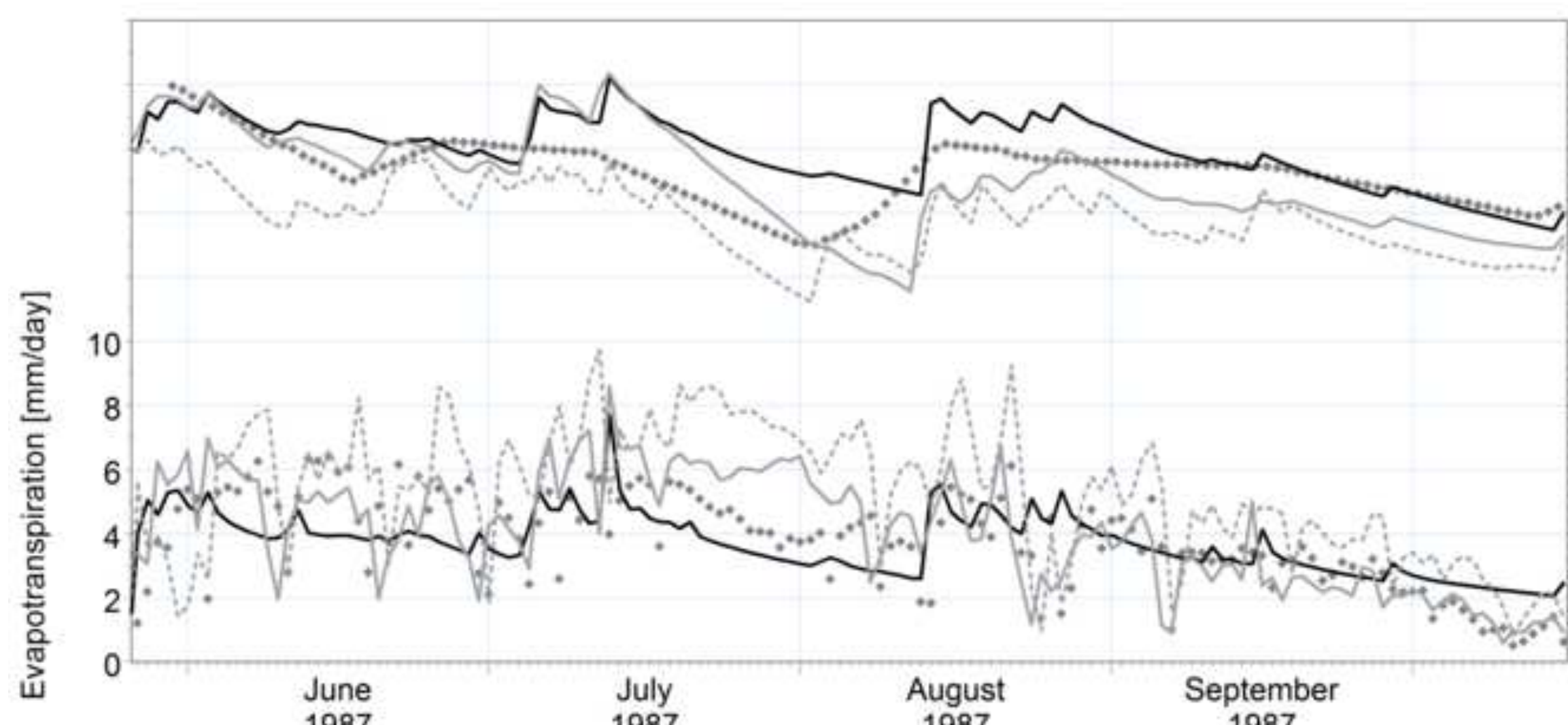

त्ञ 10

8

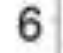

$\left.\sqrt{ } \mathrm{N}^{*}\right]+\mathrm{N}^{2} \mathrm{~N}^{2}$

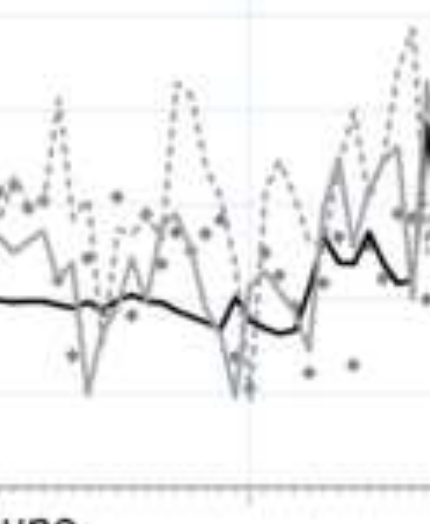

0

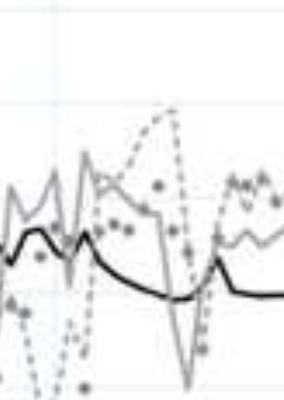
$\therefore$

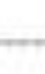

June

July
1987

August

September

$\cdot$

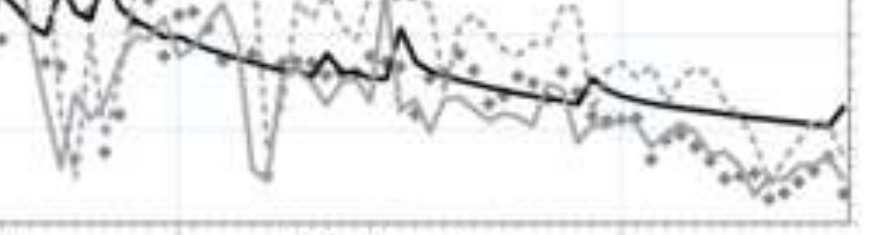

1987

1987

1987 


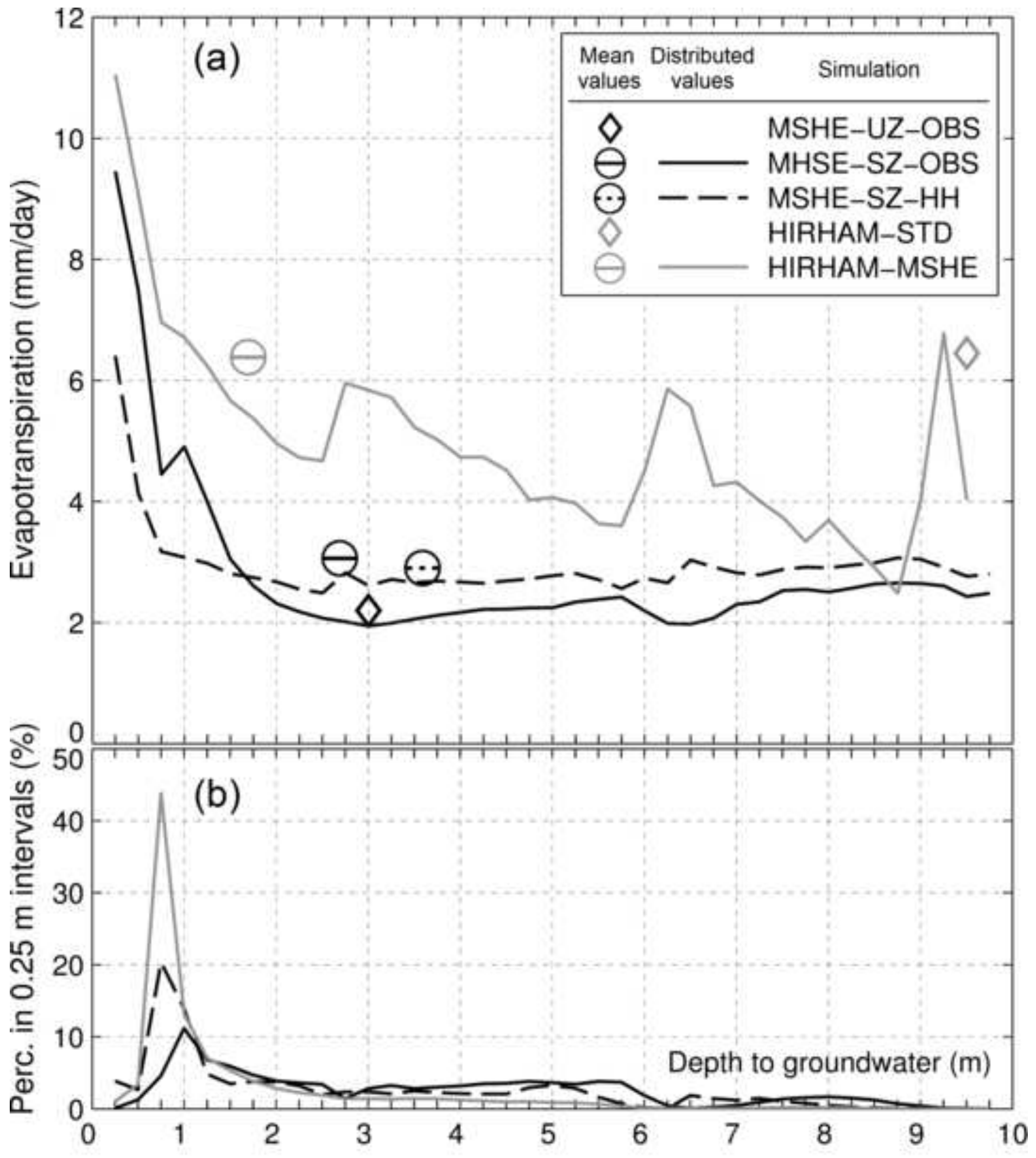

